\title{
Insentif Pajak dan Diskonto serta Implikasinya terhadap pertumbuhan Ekonomi di Jawa Barat
}

\author{
Agung Wahyu Ginanjar \\ agungwahyuginanjar@gmail.com
}

UIN Sunan Gunung Djati Bandung , Bandung, Indonesia

\begin{tabular}{ll} 
KEYWORD & ABSTRACT \\
\hline $\begin{array}{l}\text { Insentif Pajak, } \\
\text { Diskonto, }\end{array}$ & Makalah ini dilatarbelakangi oleh kebijakan pemerintah \\
Ekonomi, & mengenai insentif pajak dan diskonto yang dapat berimplikasi \\
Jawa Barat & terhadap pertumbuhan ekonomi yang difokuskan di Provinsi \\
& Jawa Barat Indonesia. Insentif pajak dapat didefinisikan \\
& sebagai segala bentuk insentif yang mengurangi beban pajak \\
& perusahaan dengan tujuan untuk mendorong perusahaaan- \\
& perusahaan tersebut untuk berinvestasi di proyek atau sektor \\
& tertentu. diskonto adalah potongan atau bunga yang harus \\
& dibayar oleh orang yang menjual wesel atau surat dagang \\
& yang diuangkan sebelum waktunya. Pertumbuhan ekonomi \\
& dapat diartikan juga sebagai proses kenaikan kapasitas \\
& produksi suatu perekonomian yang diwujudkan dalam \\
& bentuk kenaikan pendapatan nasional. Perekonomian \\
& dikatakan mengalami pertumbuhan apabila jumlah balas jasa \\
& ril terhadap penggunaan faktor-faktor produksi pada tahun \\
& tertentu lebih besar daripada tahun sebelumnya. Hasil \\
& penelitian menunjukkan bahwa insentif pajak berpengaruh \\
& negatif dan signifikan terhadap pertumbuhan ekonomi. \\
& Selain itu, diskonto berpengaruh positif dan signifikan \\
terhadap pertumbuhan ekonomi di Provinsi Jawa Barat & Indonesia. Artinya, daerah lain perlu melakukan diskonto jika \\
ingin meningkatkan pertumbuhan ekonominya.
\end{tabular}




\section{Pendahuluan}

Pertumbuhan ekonomi seringkali dijadikan sebagai target utama setiap wilayah yang ada di dunia. Asumsinya adalah dengan adanya pertumbuhan ekonomi yang tinggi diharapkan terjadi peningkatan kesejahteraan masyarakat yang ada di dalam wilayah tersebut. Lebih dari itu, hasil dari pertumbuhan ekonomi tersebut diharapkan mampu dirasakan secara merata oleh seluruh masyarakat. Namun, pada kenyataannya tidaklah demikian, pertumbuhan ekonomi yang tinggi seringkali tidak diikuti dengan adanya peningkatan kesejahteraan masyarakat secara merata (Gasparini \& Lustig, 2011).

Pertumbuhan dan peningkatan PDRB dari tahun ke tahun merupakan indikator dari keberhasilan pembangunan daerah. Sektor- sektor ekonomi yang membentuk PDRB dikategorikan menjadi sembilan sektor usaha yaitu: (1) Pertanian, (2) Pertambangan dan penggalian, (3) Industri pengolahan, (4) Listrik, gas dan air bersih, (5) Bangunan, (6) Perdagangan, hotel dan restoran, (7) Pengangkutan dan komunikasi, (8) Keuangan, persewaan dan jasa perusahaan, dan (9) Sektor jasa lainnya. Sinergi antar sektor ekonomi sangat penting dalam membentuk struktur ekonomi yang kuat. Sinergi antara sektor pertanian, industri dan jasa yang kuat akan membentuk perekonomian yang efisien, dan hal ini akan turut mendorong pertumbuhan ekonomi daerah (Sjafrizal, 2008). Semakin besar sumbangan yang diberikan oleh masing-masing sektor ekonomi terhadap PDRB suatu daerah maka pertumbuhan ekonomi akan berjalan ke arah yang lebih baik.

Pajak merupakan penyumbang terbesar terhadap pembangunan ekonomi di Jawa Barat. Pada saai ini banyak upaya pemerintah dalam memungut pajak dari masyarakat, salah satunya dengan cara pemberian keringan terhadap Wajib Pajak. Terutama memberikan insentif pajak terhadap kendaraan bermotor. Dengan insentif pajak tersebut penerimaan Daerah Provinsi Jawa Barat khusus dari pajak mengalami kenaikan dari tahun 2016 - 2020 rata-rata sebesar $18,73 \%$.

Tetapi Ekonomi Jawa Barat tahun 2019 tumbuh 5,07 persen melambat dibanding tahun 2018 sebesar 5,66 persen (y-on-y). Dari sisi produksi, pertumbuhan tertinggi dicapai oleh Lapangan Usaha Jasa Real Estate sebesar 9,54 persen. Dari sisi Pengeluaran dicapai oleh Komponen Ekspor Barang dan Jasa yang tumbuh 6,97 persen. Selain itu kebijakan melakukan insentif pajak dan adanya diskonto yang dilakukan oleh pemerintah maka akan banyak menarik investor untuk dapat menanamkan modalnya atau berinvestasi di Provinsi Jawa Barat Indonesia. 
Oleh karena itu, mengacu pada latar belakang di atas, maka dapat diasumsikan bahwa insentif pajak dan diskonto merupakan dua faktor determinan yang berpengaruh langsung terhadap pertumbuhan ekonomi. Sehingga tujuan penelitian ini untuk mengetahui pengaruh insentif pajak dan diskonto terhadap pertumbuhan ekonomi di Provinsi Jawa Barat Indonesia.

\section{Tinjauan Pustaka}

UNCTAD (United Nations Conference on Trade and Deleopment) mendefinisikan insentif pajak sebagai segala bentuk insentif yang mengurangi beban pajak perusahaan dengan tujuan untuk mendorong perusahaaan-perusahaan tersebut untuk berinvestasi di proyek atau sektor tertentu (Prasetyo, 2008). Pandangan itu juga yang di terapkan oleh Indonesia, Malaysia, dan Thailand dalam menerapkan insentif pajak.

Pengertian insentif pajak (Tax Incentive) menurut Black Law Dictionary adalah A governmental enticement, through a tax benefit, to engage in a particular activity, such as the contribution of money or property to qualified charity. (terjemahan : Sebuah penawaran dari pemerintah, melalui manfaat pajak, dalam suatu kegiatan tertentu, seperti kontribusi uang atau harta untuk kegiatan yang berkualitas).

Winardi, menyebutkan istilah insentif pajak dengan Incentive Taxation, yang artinya: Pemajakan dengan tujuan memberikan perangsang. Penggunaan pajak bukan untuk maksud menghasilkan pendapatan pemerintah saja, melainkan pula memberikan dorongan ke arah perkembangan ekonomi, dalam bidang tertentu.

Dari ketiga teori tersebut dapat ditemukan kesamaan yaitu insentif pajak merupakan sebuah fasilitas yang diberikan kepada investor agar tertarik untuk menanamkan modalnya disuatu negara. Dari definisi tersebut juga dapat disimpulkan bahwa insentif pajak merupakan alat yang dapat digunakan oleh pemerintah untuk mempengaruhi perilaku investor dalam menentukan kegiatan bisnisnya.

Menurut UNCTAD dalam bukunya Tax Incentives and Foreign Direct Investment, a Global Survey, disebutkan Classification of Tax Incentives (klasifikasi/penggolongan insentif pajak), yaitu sebagai berikut:

a. Tax holidays. Under a tax holiday, qualifying "newly established firms" are exempt from paying corporate income tax for a specified time period (e.g. five years). (terjemahan: Pembebasan Pajak. Di bawah pembebasan pajak, dikualifikasi "perusahaan yang baru didirikan" dibebaskan dari kewajiban membayar pajak penghasilan badan untuk jangka waktu tertentu (misalnya lima tahun). 
b. Investment allowances. Deductions from taxable income based on some percentage of new investment (depreciation).(terjemahan: Tunjangan investasi. Pengurangan dari penghasilan kena pajak didasarkan pada beberapa persentase investasi baru atau depresiasi)

\section{Metode}

Metode regresi panel digunakan untuk menganalisis tujuan penelitian melalui penggabungan data time series dengan data cross section, didukung oleh alat analisis regresi dan determinasi (Subakti, 2015). Tujuan dari analisis regresi adalah untuk menghitung arah korelasi variabel independen terhadap variabel dependen apakah positif atau negatif, dan untuk menghitung nilai variabel dependen jika mengalami penurunan atau peningkatan. Analisis regresi linier berganda merupakan alat untuk meramalkan pengaruh dua atau lebih nilai variabel independen terhadap variabel dependen guna membuktikan ada tidaknya hubungan fungsi antara dua atau lebih variabel independen (Sugiyono, 2005). Variabel independen dalam penelitian ini adalah sistem insentif pajak dan diskonto, sedangkan variabel dependennya adalah pertumbuhan ekonomi.

\section{Hasil dan Pembahasan}

Sebelum melakukan analisis regresi berganda, terlebih dahulu dilakukan pengujian model regresi dengan serangkaian uji asumsi klasik. Pengujian dilakukan dengan harapan hasil uji analisis regresi linier berganda dapat diketahui memenuhi atau tidak memenuhi kriteria terbaik linear unlimited estimation (BLUE) (Parenrengi \& Hendratni, 2018), misalnya data berdistribusi normal dapat dianalisis melalui uji normalitas. Jika tidak terdapat gejala autokorelasi, maka akan dianalisis melalui uji autokorelasi dengan Durbin Watson. Jika tidak terdapat multikolinieritas maka dapat dianalisis melalui uji multikolinieritas, dan jika tidak terdapat heteroskedastisitas maka dianalisis melalui uji heteroskedastisitas. Hasil analisis tersebut untuk memberikan hasil penelitian bahwa semua asumsi terpenuhi sehingga uji analisis regresi linier berganda dalam penelitian ini dapat diinterpretasikan. Pengujian analisis regresi bertujuan untuk mengetahui arah sistem insentif pajak dan diskonto terhadap pertumbuhan ekonomi apakah arah hubungan positif atau negatif, dan untuk mengestimasi nilai pertumbuhan ekonomi apakah mengalami penurunan atau peningkatan. Sehingga hasilnya dapat ditunjukkan sebagai berikut: 
Tabel 1 : Hasil Uji Analisis Regresi Berganda Pengaruh Insentif Pajak terhadap Pertumbuhan Ekonomi Provinsi Jawa Barat Coefficientsa Sumber: Data output software SPSS V. 16 (2021)

\begin{tabular}{|c|c|c|c|c|c|}
\hline \multirow[t]{2}{*}{ Model } & \multicolumn{2}{|c|}{$\begin{array}{c}\text { Unstandardized } \\
\text { Coefficients }\end{array}$} & \multirow{2}{*}{$\begin{array}{c}\begin{array}{c}\text { Standardized } \\
\text { Coefficients }\end{array} \\
\text { Beta }\end{array}$} & \multirow[t]{2}{*}{$\mathrm{t}$} & \multirow[t]{2}{*}{ Sig. } \\
\hline & B & Std. Error & & & \\
\hline \multicolumn{6}{|l|}{1 (Constant) } \\
\hline & 8.710 & .881 & & 9.890 & .002 \\
\hline \multicolumn{6}{|l|}{ Insentif Pajak } \\
\hline (X1) & -.190 & .047 & -.921 & -4.088 & .026 \\
\hline
\end{tabular}

Mengacu pada output pengolahan data melalui penggunaan Program SPSS Versi 16 diperoleh hasil persamaan regresi sebagai berikut:

Mengacu pada hasil perhitungan di atas, persamaan tersebut menunjukkan bahwa ketika insentif pajak terhadap pertumbuhan ekonomi digunakan dalam mengukur variabel independen (insentif pajak) sebesar nol (0), nilai tersebut mengukur variabel dependen (pertumbuhan eonomi) sebesar 8.710. Sehubungan dengan hal tersebut, dari hasil penelitian ini dapat dirumuskan bahwa uji koefisien regresi untuk insentif pajak sebesar -0,190 terhadap pertumbuhan ekonomi - 0,190 adalah negatif. Diasumsikan bahwa insentif pajak terhadap pertumbuhan ekonomi berpengaruh negatif.

Tabel 2 : Hasil Uji Analisis Regresi Berganda Pengaruh Diskonto terhadap Pertumbuhan Ekonomi Provinsi Jawa Barat Coefficients

Sumber: Data output software SPSS V. 16 (2021)

\begin{tabular}{|c|c|c|c|c|c|c|}
\hline \multirow[b]{2}{*}{ Model } & & \multicolumn{2}{|c|}{$\begin{array}{l}\text { Unstandardized } \\
\text { Coefficients }\end{array}$} & \multirow{2}{*}{$\frac{\begin{array}{c}\text { Standardized } \\
\text { Coefficients }\end{array}}{\text { Beta }}$} & \multirow[b]{2}{*}{$\mathrm{t}$} & \multirow[b]{2}{*}{ Sig. } \\
\hline & & B & Std. Error & & & \\
\hline 1 & (Constant) & 2.963 & 6.504 & & .456 & .680 \\
\hline & $\begin{array}{l}\text { Diskonto } \\
\text { (X2) }\end{array}$ & .350 & 1.039 & .191 & .337 & .758 \\
\hline
\end{tabular}

Mengacu pada output pengolahan data melalui penggunaan Program SPSS Versi 16 diperoleh hasil persamaan regresi sebagai berikut:

Mengacu pada hasil perhitungan di atas, persamaan tersebut menunjukkan bahwa ketika diskonto terhadap pertumbuhan ekonomi digunakan dalam mengukur variabel independen (diskonto) sebesar nol (0), nilai tersebut mengukur variabel dependen (pertumbuhan eonomi) sebesar 2.963. Sehubungan dengan hal tersebut, dari hasil penelitian ini dapat dirumuskan bahwa uji koefisien Fakultas Ekonomi dan Bisnis Islam - UIN Sunan Gunung Djati Bandung 
regresi untuk diskonto sebesar 0,350 terhadap pertumbuhan ekonomi 0,350 adalah positif. Diasumsikan bahwa diskonto terhadap pertumbuhan ekonomi berpengaruh positif.

Untuk menjelaskan secara jelas seberapa besar kontribusi variabel independen terhadap variabel dependen dilakukan perhitungan statistik dengan menggunakan uji analisis koefisien determinasi $(\mathrm{Cd})$, dimana hasilnya menunjukkan seperti berikut:

Tabel 3: Hasil Uji Analisis Koefisien Determinasi Pengaruh Insentif Pajak terhadap Pertumbuhan

Ekonomi Provinsi Jawa Barat

Model Summary

Sumber: Data output software SPSS V. 16 (2021)

$\frac{\text { Model }}{1} \frac{\mathrm{R}}{.921^{\mathrm{a}}} \frac{\mathrm{R} \text { Square }}{.848} \frac{\begin{array}{c}\text { Adjusted R } \\ \text { Square }\end{array}}{.797} \frac{\begin{array}{r}\text { Std. Error of } \\ \text { the Estimate }\end{array}}{.29208}$

Mengacu pada hasil pengolahan data melalui penggunaan Program SPSS Versi 16 diperoleh hasil uji analisis koefisien determinasi melalui R Square sebesar (0.848) atau $84.80 \%$ yang menunjukkan seberapa besar pengaruh insentif pajak sebagai variabel bebas terhadap pertumbuhan ekonomi sebagai variabel dependen. Hasil ini menunjukkan bahwa setiap perubahan pertumbuhan ekonomi dapat dijelaskan oleh insentif pajak sebesar $84,8 \%$ dan sisanya dapat dipengaruhi oleh aspek lainnya.

Tabel 4: Hasil Uji Analisis Koefisien Determinasi Pengaruh Diskonto terhadap Pertumbuhan

Ekonomi Provinsi Jawa Barat

Model Summary

Sumber: Data output software SPSS V. 16 (2021)

\begin{tabular}{|c|c|c|c|c|}
\hline Model & $\mathrm{R}$ & R Square & $\begin{array}{l}\text { Adjusted R } \\
\text { Square }\end{array}$ & $\begin{array}{l}\text { Std. Error of } \\
\text { the Estimate }\end{array}$ \\
\hline 1 & $.191^{\mathrm{a}}$ & .036 & -.285 & .73488 \\
\hline
\end{tabular}

Mengacu pada hasil pengolahan data melalui penggunaan Program SPSS Versi 16 diperoleh hasil uji analisis koefisien determinasi melalui $R$ Square sebesar (0.036) atau 3.6\% yang menunjukkan seberapa besar pengaruh diskonto sebagai variabel bebas terhadap pertumbuhan ekonomi sebagai variabel dependen. Hasil ini menunjukkan bahwa setiap perubahan pertumbuhan ekonomi dapat dijelaskan oleh diskonto sebesar 3,6\% dan sisanya dapat dipengaruhi oleh aspek lainnya 
Tabel 5: Hasil Uji Analisis Koefisien Determinasi Pengaruh Insentif Pajak dan Diskonto terhadap Pertumbuhan Ekonomi Provinsi Jawa Barat

Model Summary

Sumber: Data output software SPSS V. 16 (2021)

\begin{tabular}{|c|c|c|c|c|}
\hline Model & $\mathrm{R}$ & R Square & $\begin{array}{l}\text { Adjusted R } \\
\text { Square }\end{array}$ & $\begin{array}{l}\text { Std. Error of } \\
\text { the Estimate }\end{array}$ \\
\hline 1 & $.993^{\mathrm{a}}$ & .985 & .970 & .11152 \\
\hline
\end{tabular}

Mengacu pada hasil pengolahan data melalui penggunaan Program SPSS Versi 16 diperoleh hasil uji analisis koefisien determinasi melalui $\mathrm{R}$ Square diperoleh sebesar (0.985) atau 98,5\% yang menunjukkan seberapa besar insentif pajak dan diskonto terhadap pertumbuhan ekonomi sebagai variabel dependen. Hasil ini menunjukkan bahwa setiap perubahan pertumbuhan ekonomi dapat dijelaskan oleh insentif pajak san diskonto sebesar $98,5 \%$.

\section{Hasil}

Berdasarkan penelitian dan hasil analisis di atas, peneliti mendapatkan hasil, menurut teori bahwa diskonto akan berpengaruh positif terhadap pertumbuhan ekonomi. Berdasarkan perspektif praktis, hasil uji analisis determinasi sederhana dalam penelitian ini menunjukkan bahwa variabel diskonto berpengaruh positif dan signifikan terhadap pertumbuhan ekonomi. Jika dianalisis melalui arah perspektif hubungan, diskonto terhadap pertumbuhan ekonomi juga berpengaruh positif dan signifikan terhadap pertumbuhan ekonomi.

\section{Kesimpulan}

Berdasarkan hasil penelitian dapat disimpulkan bahwa insentif pajak berpengaruh tetapi tidak signifikan terhadap pertumbuhan ekonomi Provinsi Jawa Barat yang ditunjukkan melalui hasil analisis regresi insentif pajak terhadap pertumbuhan ekonomi. Hal ini memiliki implikasi terhadap pertumbuhan ekonomi. Selain itu, diskonto berpengaruh signifikan terhadap pertumbuhan ekonomi dengan arah hubungan positif, sehingga insentif pajak dan diskonto masing-masing berpengaruh secara simultan terhadap pertumbuhan ekonomi, namun arah hubungannya terbukti pada pandangan yang sangat berbeda. 


\section{Daftar Pustaka}

Natawiria, Asep Suryana dan Riduwan. 2010. Statistika Bisnis. Bandung: Alfabeta.

Narmiwati, Umi. Metodologi Penelitian Kualitatif dan Kuantitatif, Teori dan Aplikasi. Bandung: Agung Media.

Nazir, Moh.2014. Metode Penelitian. Bogor: Ghalia Indonesia.

Ridwan dan Adkon. Rumus dan Data dalam Analisis Statistik untuk Penelitian. Bandung: Alfabeta.

Sekaran, Uma. 2014. Metodologi Penelitian untuk Bisnis. Jakarta: Salemba Empat.

Sekaran, Uma. 2012. Metode Penelitian untuk Bisnis, cetakan 2. Jakarta: PT. Selemba Empat.

Sugiyono. 2016. Statistika untuk Penelitian. Bandung: Alfabeta.

Sugiyono. 2017. Metode Penelitian Kuantitatif, Kualitatif, dan R\&D. Bandung: Alfabeta.

Sujarweni, V. Wiratna. 2015. SPSS untuk Penelitian. Yogyakarta: Pustaka Baru Press.

Suliyanto. 2011. Ekonometrika Terapan: Teori dan Aplikasi dengan SPSS. Yogyakarta: Andi.

Hamijaya, Marselina. 2015. Pengaruh Insentif Pajak dan Insentif Non Pajak Terhadap Manajemen Laba Saat Terjadi Penurunan Tarif Pajak Penghasilan Badan Pada Perusahaan Manufaktur Yang Terdaftar Di Bursa Efek Indonesia. Jurnal Akuntansi Bisnis, Vol. XIV No. 27 September 2015

Haryanto, Tommy Prio. 2012. Pengaruh Pengeluaran Pemerintah Terhadap Pertumbuhan Ekonomi Kabupaten/Kota di Provinsi Jawa Tengah Tahun 2007-2011. Journal Economics Development Analysis, ISSN 2252-6889, Vol. 2 (3) (2013).

Hidayat, Kholid. 2016. Pengaruh Corporate Social Responsibility Terhadap Agresivitas Pajak Dengan Insentif Pajak Sebagai Pemoderasi (Studi Pada Perusahaan Pertambangan Yang Terdaftar Di Bei). Jurnal JIAFE, Vol. 2 No. 2, 2016.

Jubaedah, Dedah, Dkk. 2020. The Effect Of Spin-Off System and The Third Party Funds On Return On Equity Ratio Of Islamic Bank In Indonesia. International Journal Of Critical Riviews, ISSN- 2394-5125 VOL 7, ISSUE 13, 2020.

Kartika, Rohana. 2011. Pengaruh insentif pajak terhadap peningkatan investasi di Indonesia. Jurnal Fakultas Ekonomi dan Bisnis Universitas Brawijaya.

Maqin. Abdul. 2011. Pengaruh Kondisi Infrastruktur terhadap Pertumbuhan Ekonomi di Jawa Barat. Jurnal Trikonomika Volume 10, No. 1, Juni 2011, Hal. 10-18 ISSN 1411-514X. 